\title{
Seroprevalence of hepatitis B virus, hepatitis C virus, and human immunodeficiency virus among volunteer blood donors in the National Blood Transfusion Center of Lomé
}

\author{
Liza Koboyo Nadjir, Malewe Kolou, Gnatoulma Katawa, \\ Alexander Kwame Kwarteng, Abdoul Raouf Issa, \\ Hèzouwè Magnang, Koffi Mawussi, Lochina Feteke, \\ Koffi Yvon Segbena
}

\section{ABSTRACT}

Aims: This study aimed to evaluate the prevalence of hepatitis B virus (HBV), hepatitis $C$ virus (HCV), and human immunodeficiency virus (HIV) at the Centre National de Transfusion (CNTS) of Lomé, Togo. Methods: This is a cross-sectional study, which included volunteer blood donors from 2011-2015 at the CNTS of Lomé. The age ranged from 18-60 years old. All donors were screened for $\mathrm{HBV}, \mathrm{HCV}$ and HIV using ELISA and the seroprevalence of these viruses was calculated using Graph Pad

Liza Koboyo Nadjir ${ }^{1}$, Malewe Kolou², Gnatoulma Katawa ${ }^{3}$, Alexander Kwame Kwarteng ${ }^{4}$, Abdoul Raouf Issa ${ }^{5}$, Hèzouwè Magnang $^{6}$, Koffi Mawussi ${ }^{7}$, Lochina Feteke ${ }^{8}$, Koffi Yvon Segbena $^{9}$

Affiliations: ${ }^{1}$ Biologist Medical doctor, Liza Koboyo NADJIR, CNTS of Lomé, Université de Lomé, Lomé, Togo; ${ }^{2}$ Biologist Medical doctor, Malewe KOLOU, CHU Campus, University of Lomé, Lomé, Togo; ${ }^{3} \mathrm{PhD}$, Gnatoulma Katawa, ESTBA, Université de Lomé, Lomé, Togo; ${ }^{4} \mathrm{PhD}$, Alexander Kwame Kwarteng, Kumasi Centre for Collaborative Research in Tropical Medicine, Kumassi, Ghana; ${ }^{5} \mathrm{PhD}$, Abdoul Raouf Issa, BIOLIM, University of Lomé, Lomé, Togo; ${ }^{6}$ Biologist Medical Doctor, Hézouwè MAGNANG, CNTS of Lomé, University of Lomé, Lomé, Togo; ' ${ }^{7}$ Biologist Medical Doctor, Koffi MAWUSSI, CNTS of Lomé, University of Lomé, Lomé, Togo; ${ }^{8}$ Biologist Medical Doctor, Lochina FETEKE, CNTS of Lomé, University of Lomé, Lomé, Togo; ${ }^{9}$ Professor, Koffi Yvon SEGBENA, CHU Campus, University of Lomé, Lomé, Togo.

Corresponding Author: Liza Koboyo NADJIR, Lomé, Togo, BP: 4090 Lomé, Togo; Email:lizanadjir@yahoo.fr

Received: 13 June 2017

Accepted: 21 July 2017

Published: 27 October 2017
Prism software. Results: Male donors (86.44\%) were significantly more represented than female (13.71\%). Regular donors $(72.2 \%)$ were more than first time donors $(28 \%, p<0.001)$. The overall seroprevalence during the study period was $2.63 \%, 1.58 \%$ and $0.92 \%$ for $\mathrm{HBV}$, HCV and HIV, respectively. The seroprevalence of these viruses in blood donors decreased from 2011-2015. The proportion of HBV among blood-borne viral infection represented, $48.81 \%, 54.16 \%, 51.71 \%, 46.71 \%$ and $58.10 \%$ in 2011, 2012, 2013, 2014 and 2015, respectively. Conclusion: This study permitted to monitor the dynamics of HBV, HCV and HIV in blood donors for five years in Lomé, and revealed the need to reinforce screening, preventive and sensitization strategies to improve transfusion safety in Togo.

Keywords: Centre National de Transfusion (CNTS), Hepatitis B virus (HBV), Hepatitis C virus (HCV), Human immunodeficiency virus (HIV)

\section{How to cite this article}

Nadjir LK, Kolou M, Katawa G, Kwarteng AK, Issa AR, Magnang H, Koffi M, Feteke L, Segbena KY. Seroprevalence of hepatitis B virus, hepatitis C virus, and human immunodeficiency virus among volunteer blood donors in the National Blood Transfusion Center of Lomé. Int J Blood Transfus Immunohematol 2017;7:41-45.

Article ID: 100033IJBTINK2017 


\section{MATERIALS AND METHODS}

This cross-sectional study was based on data analyzed from records of blood donors containing results of serological screening. We used the records from 20112015. All donors signed an informed consent form. Donors are male and female with an age range of 18-60 years old. Volunteer blood donors were screened first by clinical examination including their medical history and second by biological blood tests such as HBV, HCV and HIV. Human immunodeficiency virus was tested using either Genscreen ULTRA HIV Ag-Ab ${ }^{\circledR}$ (BIO-RAD, Marnes-laCoquette, France) or VIRONOSTIKA ${ }^{\circledR}$ HIV (bioMérieux, Marcy-l'Etoile, France). Hepatitis B virus was tested using either Monolisa HBsAg ${ }^{\circledR}$ (Bio-RAD, Marnes-la-Coquette, France), Murex $\operatorname{HBsAg}^{\circledR}$ (DIASORIN, Dartford, UK) or Inteck HBsAg ${ }^{\circledR}$. For HCV testing, either Murex anti$\mathrm{HCV}^{\circledR}$ (DIASORIN, Dartford, UK) or Access ${ }^{\circledR} \mathrm{HCV} \mathrm{Ab}$ Plus (Bio-RAD, Marnes-la-Coquette, France) was used.

\section{Statistical analysis}

Seroprevalence was calculated for each infection using Graph Pad Prism 5.02 software. Chi-square was used for statistical analysis. A p-value $<0.05$ was considered significant.

\section{RESULTS}

\section{Study population characteristics}

Table 1 gives the characteristics of the study population. Volunteer blood donors aged from 18-60 years. Males were more represented than females $(86.44 \%$ vs $13.71 \%$, $\mathrm{p}<0.0001)$. The number of blood donors ranged from 27,336-35,777 donors in the period of 2011-2015. The number of donors in 2014 was significantly higher ( $\mathrm{p}$ $<$ 0.05). In addition, regular donors (72.20\%) were statistically more represented than first time donors (28\%, p < 0.0001). Interestingly, for each year, the number of regular donors was also higher than first time donors. Lomé.

Table 1: Population characteristics

\begin{tabular}{|c|c|c|c|c|c|c|c|c|c|}
\hline & \multicolumn{4}{|c|}{ Gender } & \multicolumn{4}{|c|}{ Type of donors } & \multirow[t]{3}{*}{ Total } \\
\hline & \multicolumn{2}{|c|}{ Female } & \multicolumn{2}{|c|}{ Male } & \multicolumn{2}{|c|}{ Regular donors } & \multicolumn{2}{|c|}{ First time donors } & \\
\hline & $\mathbf{N}$ & $\%$ & $\mathbf{N}$ & $\%$ & $\mathbf{N}$ & $\%$ & $\mathbf{N}$ & $\%$ & \\
\hline 2011 & 4128 & 15.1 & 23208 & 84.9 & 18315 & 67 & 9021 & 33 & 27336 \\
\hline 2012 & 3633 & 12.84 & 24663 & 87.16 & 20939 & 74 & 7357 & 26 & 28296 \\
\hline 2013 & 3561 & 13.03 & 23966 & 86.94 & 20818 & 75 & 6739 & 25 & 27557 \\
\hline 2014 & 4990 & 13.95 & 30787 & 86.05 & 25402 & 71 & 10375 & 29 & $35777^{(2)}$ \\
\hline 2015 & 4232 & 13.4 & 27353 & 86.6 & 23373 & 74 & 8212 & 26 & 31585 \\
\hline $\begin{array}{l}\text { Mean } \\
\pm \text { SD }\end{array}$ & $4109 \pm 574.1$ & $13.71 \pm 0.88$ & $25995^{(1)} \pm 3101$ & $86.44^{(1)} \pm 0.92$ & $21769^{(1)} \pm 2706$ & $72.20^{(1)} \pm 1.46$ & $8341 \pm 1427$ & $28 \pm 1.64$ & $30110^{(1)} \pm 3590$ \\
\hline
\end{tabular}

${ }^{(1)} \mathrm{p}<0.0001,{ }^{(2)} \mathrm{p}<0.05$ 


\section{Seroprevalence of $\mathrm{HCV}, \mathrm{HBV}$ and $\mathrm{HIV}$ from 2011-2015}

To ensure the security of blood transfusion and to avoid contamination, CNTS screened systematically all donors for HBV, HCV and HIV. Figure 1 shows the prevalence of HBV, HCV and HIV. The seroprevalence of HBV was higher than HCV and HIV from 2011-2015. The mean prevalence of HBV from 2011-2015 was $3.63 \pm 0.35 \%$ while HCV and HIV were $1.58 \pm 0.56 \%$ and $0.92 \pm 0.15 \%$ respectively. The seroprevalence of $\mathrm{HBV}$ was the highest and was observed in 2011. The lowest seroprevalence of HBV was observed in 2013. Regarding HCV, the highest prevalence was observed in 2012 and lowest in 2015. For HIV, there was no difference between 2011 and 2015. In general, we found that the seroprevalence of these viruses in blood donors decreased from 2011-2015. However, there was a peak in 2014. In addition, the proportion of HBV among blood-borne viral infection represented, $48.81 \%, 54.16 \%, 51.71 \%, 46.71 \%$ and $58.10 \%$ in 2011, 2012, 2013, 2014 and 2015, respectively (Figure 2). This indicates that $\mathrm{HBV}$ is a big concern for blood transfusion safety in the CNTS.

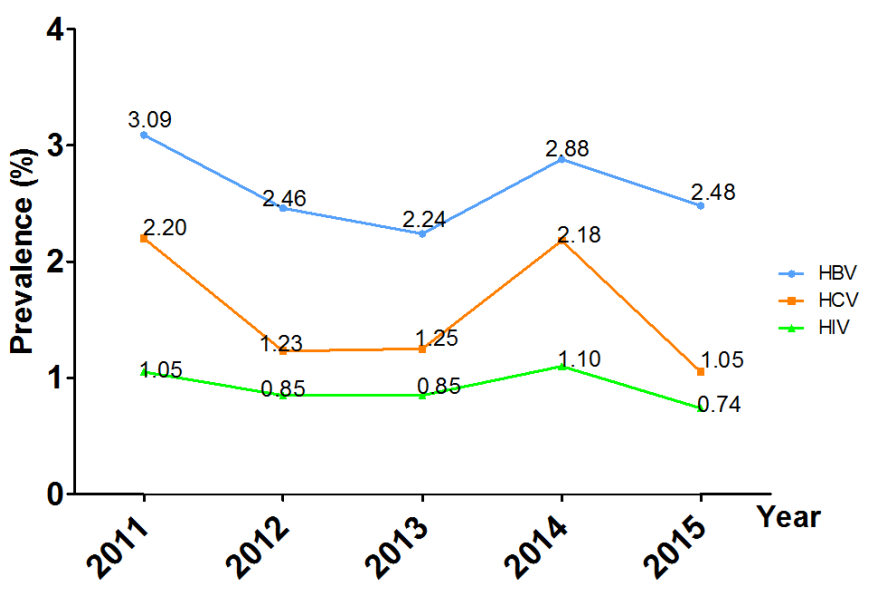

Figure 1: Prevalence of HBV, HCV and HIV from 2011-2015.

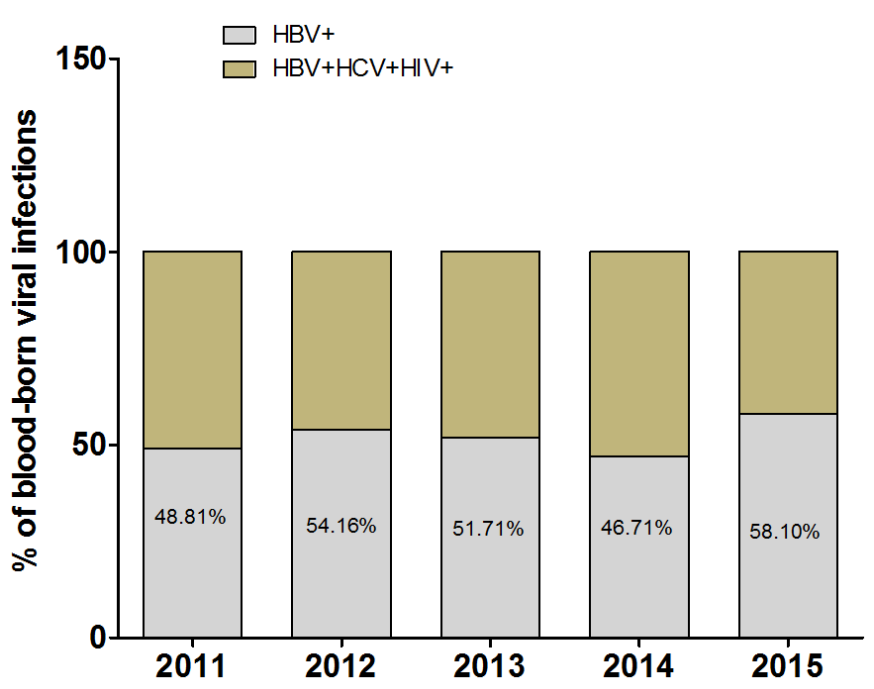

Figure 2: Blood-borne viral infection.

\section{DISCUSSION}

Blood transfusion is one of the most important therapeutic options of life-saving intervention for recipients who are in diseased or non-diseased conditions with severe blood loss. However, it is associated with certain risks, which can lead to adverse consequences that may cause acute or delayed complications and bring the risk of transfusion-transmissible infections including HIV, hepatitis B and hepatitis C and syphilis [7-9]. Therefore, the National Blood Transfusion Center of Lomé (CNTS) qualifies blood for transfusion by testing HBV, HCV, HIV and syphilis. This study aimed to evaluate the seroprevalence of HBV, HCV and HIV from 2011-2015. We consider a cohort of donors including regular donors and first time donors. The number of donors ranged from 27,336-35,777 and was higher in 2014. In our study, male blood donors were higher compared to female. Adjelic et al. found a similar trend in Serbian blood donors [10]. $\mathrm{Ou}$ et al. found in Hong Kong that male donors were more likely to be frequent donors [11]. First time blood donors were lesser than regular donors who participated in the study. This can probably be attributed to the low engagement of people in blood donation exercises despite its enormous benefits. Moore et al. in a similar study observed that in a cohort of 48,725 donors, only $3 \%$ were first time donors [12], therefore supporting the need for advocacy and community intervention exercises to increase the pool of blood donors for this life-saving exercise.

The study reported seroprevalence of $3.63 \%, 1.58 \%$ and $0.92 \%$ for HBV, HCV and HIV over a five-year period (2011-2015). The highest seroprevalence was found for HBV followed by HCV and HIV. From 20042014, Farshadpour et al. found that the seroprevalence of HBV was higher than HCV and HIV but the overall seroprevalence of HBV, HCV and HIV was lower compared to our study [8]. Many studies showed that the prevalence of $\mathrm{HBV}$ in blood transfusion was higher than HCV $[13,14]$.

In 2013, Motayo et al. [15] found a seroprevalence of $10 \%$ for HBsAg, similar to a scenario in Equatorial Guinea with a seroprevalence of $10.1 \%$ for HBV [16]. However, in our study the seroprevalence of HBV was $3.63 \%$ from 2012-2015. In contrast, the seroprevalence of HCV in their study (1.5\%) was similar to our study (1.58\%). Seroprevalence of HBV has been widely evaluated in Togo [17]. While the seroprevalence of HBV among HIVinfected individuals was 9.7\% [18], Segbena et al. found a prevalence of $20.2 \%$ in patients with sickle-cell disease in Togo [19]. In this study, the prevalence of HCV was $1.58 \%$ in volunteer blood donors at the blood transfusion center in Lomé. Agbodjan et al. found a prevalence of 3.3\% at the University Hospital of Lomé [20]. In addition, Segbena et al. found the HCV prevalence of $6.5 \%$ in patients with sickle-cell disease in Togo [19]. The prevalence of HCV has been reported as 1.0\% in the general population of Burkina Faso recently [21]. The seroprevalence of HBV 
and HCV in West African countries was $12.5 \%$ and $0.5 \%$ respectively [22]. Regarding HIV infection, the seroprevalence in our study was $0.92 \%$. The prevalence of HIV among female sex workers in Togo was $13.1 \%$ in 2011 [23]. This prevalence was 5.5\% among drug users in Lomé [24]. Furthermore, two recent studies similarly conducted at hospital blood banks in Cameroon found the seroprevalence of HBV to be $10.1 \%$ and $12.1 \%$ and HCV prevalence to account for $4.8 \%$ and $1.14 \%$ respectively $[25,26]$.

Interestingly, there is increasing evidence that points to decrease in the incidence of acute hepatitis B and the prevalence of hepatitis B surface antigens chronic carriers in several countries, particularly low and middle income countries due to the successful vaccination programs [27]. However, while we recorded a low level of HBV seroprevalence, that of $\mathrm{HCV}$ was not significantly affected compared to other studies. This, therefore, questions the effectiveness of the recent and ongoing viral vaccination programs in Togo. In general, the prevalence of HBV, HCV and HIV was lower in our study. This could be that in blood transfusion the donors were selected and were apparently healthy whereas in the other studies the population was people at risk.

\section{CONCLUSION}

The present study assessed the seroprevalence of major viral infections of particular interest to blood transfusion among individuals in Lomé, Togo. We reported that HBV was very common among the transfusion-associated infections, and thus poses an eminent risk to recipients. In addition, our data showed the need to reinforce screening, prevention and sanitization strategies to improve transfusion safety in Togo.

\section{$* * * * * * * * *$}

\section{Author Contributions}

Nadjir Liza Koboyo - Substantial contributions to conception and design, Acquisition of data, Analysis and interpretation of data, Drafting the article, Final approval of the version to be published

Kolou Malewe - Substantial contributions to conception and design, Acquisition of data, Analysis and interpretation of data, Revising it critically for important intellectual content, Final approval of the version to be published

Katawa Gnatoulma - Substantial contributions to conception and design, Acquisition of data, Analysis and interpretation of data, Drafting the article, Final approval of the version to be published

Kwarteng Alexander Kwame - Analysis and interpretation of data, Drafting the article, Revising it critically for important intellectual content, Final approval of the version to be published

ISSA Abdoul Raouf - Substantial contributions to conception and design, Drafting the article, Revising it critically for important intellectual content, Final approval of the version to be published

Magnang Hèzouwè - Substantial contributions to conception and design, Drafting the article, Revising it critically for important intellectual content, Final approval of the version to be published

Mawussi Koffi - Substantial contributions to conception and design, Drafting the article, Revising it critically for important intellectual content, Final approval of the version to be published

Feteke Lochina - Substantial contributions to conception and design, Drafting the article, Revising it critically for important intellectual content, Final approval of the version to be published

Segbena Koffi Yvon - Substantial contributions to conception and design, Revising it critically for important intellectual content, Final approval of the version to be published

\section{Guarantor}

The corresponding author is the guarantor of submission.

\section{Conflict of Interest}

Authors declare no conflict of interest.

\section{Copyright}

(C) 2017 Nadjir Liza Koboyo et al. This article is distributed under the terms of Creative Commons Attribution License which permits unrestricted use, distribution and reproduction in any medium provided the original author(s) and original publisher are properly credited. Please see the copyright policy on the journal website for more information.

\section{REFERENCES}

1. Seo DH, Whang DH, Song EY, Han KS. Occult hepatitis B virus infection and blood transfusion. World J Hepatol 2015 Mar 27;7(3):600-6.

2. Viet L, Lan NT, Ty PX, et al. Prevalence of hepatitis $\mathrm{B}$ \& hepatitis $\mathrm{C}$ virus infections in potential blood donors in rural Vietnam. Indian J Med Res 2012 Jul;136(1):74-81.

3. Dongdem JT, Kampo S, Soyiri IN, Asebga PN, Ziem JB, Sagoe K. Prevalence of hepatitis B virus infection among blood donors at the Tamale Teaching Hospital, Ghana (2009). BMC Res Notes 2012 Feb 22;5:115.

4. Al-Rubaye A, Tariq Z, Alrubaiy L. Prevalence of hepatitis B seromarkers and hepatitis $\mathrm{C}$ antibodies in blood donors in Basra, Iraq. BMJ Open Gastroenterol 2016 Jan 4;3(1):eoooo67.

5. Nkrumah B, Owusu M, Frempong HO, Averu P. Hepatitis B and C viral infections among blood donors from rural Ghana. Ghana Med J 2011 Sep;45(3):97100.

6. Ampofo W, Nii-Trebi N, Ansah J, et al. Prevalence of blood-borne infectious diseases in blood donors in Ghana. J Clin Microbiol 2002 Sep;40(9):3523-5. 
7. Tafesse TB, Gebru AA, Gobalee S, et al. Seroprevalence and diagnosis of HIV, HBV, HCV and syphilis infections among blood donors. Hum Antibodies 2017;25(1-2):39-55.

8. Farshadpour F, Taherkhani R, Tajbakhsh S, et al. Prevalence and trends of transfusion-transmissible viral infections among blood donors in south of Iran: An eleven-year retrospective study. PLoS One 2016 Jun 16;11(6):e0157615.

9. Yang S, Jiao D, Liu C, et al. Seroprevalence of human immunodeficiency virus, hepatitis $\mathrm{B}$ and $\mathrm{C}$ viruses, and Treponema pallidum infections among blood donors at Shiyan, Central China. BMC Infect Dis 2016 Oct 1;16(1):531.

10. Andjelic D. Volunteer blood donors: Relation between gender and motivation. [Article in Serbian]. Srp Arh Celok Lek 1991 Jul-Aug;119(7-8):208-11.

11. Ou Y, Yau KK, Poon CM, Hui YV, Lee SS, Lee CK. Donation frequency and its association with demographic characteristics: A 1-year observational study. Transfus Med 2015 Dec;25(6):366-73.

12. Moore C, Bolton T, Walker M, et al. Recruitment and representativeness of blood donors in the INTERVAL randomised trial assessing varying inter-donation intervals. Trials 2016 Sep 20;17(1):458.

13. Tiwari BR, Ghimire P, Kandel SR, Rajkarnikar M. Seroprevalence of HBV and HCV in blood donors: A study from regional blood transfusion services of Nepal. Asian J Transfus Sci 2010 Jul;4(2):91-3.

14. Nagalo MB, Sanou M, Bisseye C, et al. Seroprevalence of human immunodeficiency virus, hepatitis B and $\mathrm{C}$ viruses and syphilis among blood donors in Koudougou (Burkina Faso) in 2009. Blood Transfus 2011 Oct;9(4):419-24.

15. Motayo BO, Faneye AO, Udo UA, Olusola BA, Ezeani I, Ogiogwa JI. Seroprevalence of transfusion transmissible infections (TTI), in first time blood donors in Abeokuta, Nigeria. Afr Health Sci 2015 Mar;15(1):19-24.

16. Xie DD, Li J, Chen JT, et al. Seroprevalence of human immunodeficiency virus, hepatitis B virus, hepatitis $\mathrm{C}$ virus, and treponema pallidum infections among blood donors on Bioko Island, Equatorial Guinea. PLoS One 2015 Oct 8;10(10):eo139947.

17. Dorkenoo AM, Kolou M, Sawadogo H, et al. Hepatitis $B$ virus serologic status among hospital health care staff in Lome. [Article in French]. Med Sante Trop 2014 Jul-Sep;24(3):266-70.

18. Patassi A, Benaboud S, Landoh DE, et al. Hepatitis B infection in HIV-1-infected patients receiving highly active antiretroviral therapy in Lomé, Togo: Prevalence and molecular consequences. S Afr Med J 2016 May 10;106(6).

19. Ségbéna AY, Prince-David M, Kagoné TS, Dagnra AY. Human immunodeficiency virus, hepatitis $\mathrm{C}$ virus and hepatitis B viruses in patients with sickle-cell disease in Togo. [Article in French]. Transfus Clin Biol 2005 Dec;12(6):423-6.

20. Agbodjan E, Prince-David M, Nicot T, Dagnra C, Denis F. Serologic and genomic research by PCR of hepatitis $\mathrm{C}$ virus in different populations in Lome (Togo). [Article in French]. Bull Soc Pathol Exot 1995 Apr;88(5):219-24.

21. Tao I, Compaoré TR, Diarra B, et al. Seroepidemiology of hepatitis $\mathrm{B}$ and $\mathrm{C}$ viruses in the general population of burkina faso. Hepat Res Treat 2014;2014:781843.

22. Jaquet A, Wandeler G, Tine J, et al. HIV infection, viral hepatitis and liver fibrosis among prison inmates in West Africa. BMC Infect Dis 2016 Jun 6;16:249.

23. Pitché P, Gbetoglo K, Saka B, et al. HIV prevalence and behavioral studies in female sex workers in Togo: A decline in the prevalence between 2005 and 2011. Pan Afr Med J 2013 Jun 21;15:62.

24. Ekouevi DK, Coffie PA, Salou M, et al. HIV seroprevalence among drug users in Togo. [Article in French]. Sante Publique 2013 Jul-Aug;25(4):491-8.

25. Noubiap JJ, Joko WY, Nansseu JR, Tene UG, Siaka C. Sero-epidemiology of human immunodeficiency virus, hepatitis $B$ and $C$ viruses, and syphilis infections among first-time blood donors in Edea, Cameroon. Int J Infect Dis 2013 Oct;17(10):e832-7.

26. Fouelifack Ymele F, Keugoung B, Fouedjio JH, Kouam N, Mendibi S, Dongtsa Mabou J. High rates of hepatitis B and C and HIV infections among blood donors in Cameroon: A proposed blood screening algorithm for blood donors in resource-limited settings. J Blood Transfus 2012;2012:458372.

27. Zampino R, Boemio A, Sagnelli C, et al. Hepatitis $\mathrm{B}$ virus burden in developing countries. World $\mathrm{J}$ Gastroenterol 2015 Nov 14;21(42):11941-53.
Access full text article on other devices

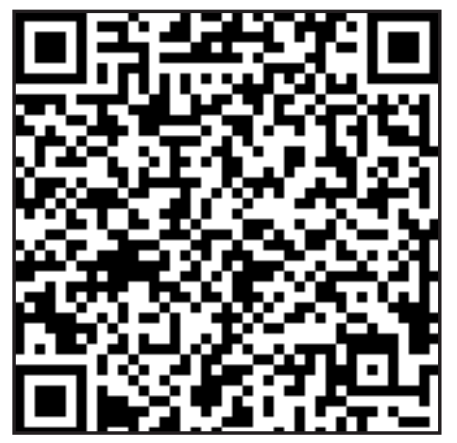

Access PDF of article on other devices

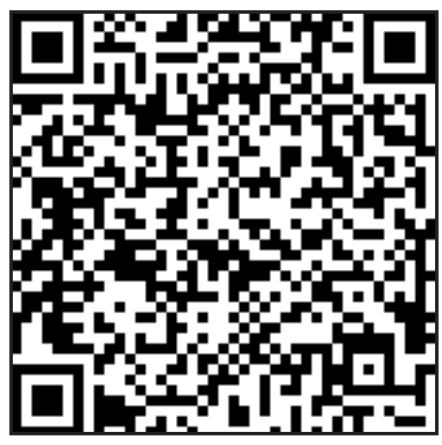

